\title{
The optimal Fontan operation: Lateral tunnel or extracardiac conduit?
}

\author{
Michael Daley, MD, ${ }^{a, b, c}$ and Yves d'Udekem, $\mathrm{MD}, \mathrm{PhD}^{\mathrm{b}, \mathrm{c}, \mathrm{d}}$
}

The most widely adopted variations of the Fontan procedure are the extracardiac conduit (ECC) and the lateral tunnel (LT). Over the last decade, there seemed to have been a shift in our practice, with the majority of the Fontan operations being the ECC, on the premise of the simplicity of this procedure and the expectation that it can better prevent the late occurrence of arrhythmias. A recent article in the Journal by a team from Boston demonstrated that in their hands, the ECC was associated with worse early outcomes compared with the LT. ${ }^{1}$ We reviewed the existing literature to identify whether one of these techniques is superior to the other.

Here we performed a search of the PubMed database to identify studies with early and late outcomes. Inclusion criteria included (1) $>200$ patients, (2) published from 2005 onward, and (3) $>50 \%$ with LT and ECC. Fourteen articles were identified for early outcomes, and 11 were identified for late outcomes (Tables 1 and 2).

First reported by Puga and colleagues ${ }^{18}$ in 1987 to address the issue of atrial septation, the LT technique became a major modification to the Fontan operation following a series of detailed hydrodynamic studies by de Leval. ${ }^{19}$ His work demonstrated that chamber pulsation (as with right atrial contraction), sharp corners, and regions of expansion increase the degree of turbulence, energy loss, and effective stenosis in the chamber and/or downstream vessel/conduit. De Leval and colleagues ${ }^{19}$ confirmed the hydrodynamic benefits of the linearized inferior vena cava (IVC) flow to the pulmonary vasculature through a lateral tunnel.

Humes and colleagues ${ }^{20}$ and Marcelletti and colleagues ${ }^{21}$ and later reported the successful use of an extracardiac conduit. Its hypothesized benefits were the avoidance of intra-atrial prosthetic material, reduced risk of pulmonary venous obstruction, and potential reduced risk of supraventricular arrhythmias associated with atrial incisions, suture

\footnotetext{
From the a Department of Cardiac Surgery, The Royal Children's Hospital, Melbourne, Australia; ${ }^{b}$ Department of Paediatrics, The University of Melbourne, Melbourne, Australia; ' Murdoch Children's Research Institute, Melbourne, Australia; and ${ }^{\mathrm{d}}$ Division of Cardiac Surgery, Children's National Hospital, Washington, DC. Received for publication Aug 13, 2020; revisions received Nov 9, 2020; accepted for publication Nov 26, 2020; available ahead of print Dec 28, 2020.

Address for reprints: Yves d'Udekem, MD, PhD, Division of Cardiac Surgery, Children's National Hospital, 111 Michigan Ave NW, Suite W3-402, Washington, DC 20010 (E-mail: yves.dudekem@ @ childrensnational.org).

J Thorac Cardiovasc Surg 2021;162:1825-34

$0022-5223 / \$ 36.00$

Copyright (C) 2020 by The American Association for Thoracic Surgery

https://doi.org/10.1016/j.jtcvs.2020.11.179
}

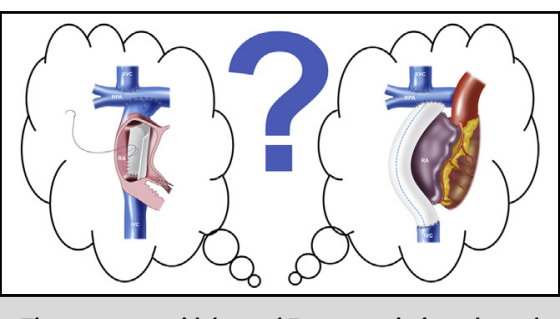

The two most widely used Fontan variations: lateral tunnel and extracardiac conduit.

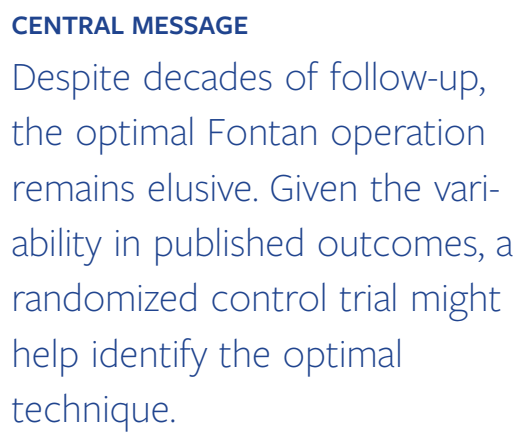

lines, and gradual distension of the atrial portion of the Fontan pathway.

\section{FONTAN CIRCULATION FLUID DYNAMICS STUDIES}

Minimizing Fontan pathway energy loss is paramount for avoiding both early and late complications. In addition, surgeons need to keep in mind that they have to construct the geometry of the anastomoses in a way that allows hepatic blood flow to both lungs, because the lack of this flow has been associated with the development of pulmonary arteriovenous malformations.

The work by de Leval and later confirmed by Sharma and colleagues $^{22}$ and Lardo and colleagues ${ }^{23}$ demonstrated that a degree of caval offset and flaring of the anastomosis can significantly reduce flow collision, recirculation, and subsequently energy loss. ${ }^{24}$ Tang and colleagues ${ }^{25}$ demonstrated significant variability within both LT and ECC based on the anastomotic positions and angulations. ${ }^{25}$

Lardo and colleagues, ${ }^{23}$ in their comparison of intraatrial tunnel and extracardiac conduit, showed significantly lower energy loss in the ECC model. They also demonstrated that a mismatch in IVC-Fontan conduit size results in more energy loss, with a 1:1 size ratio as the most efficient. This further supports de Leval's original report 
TABLE 1. Early outcomes of contemporary techniques

\begin{tabular}{|c|c|c|c|c|c|}
\hline Authors & Dates & Number & $\begin{array}{c}\text { Early } \\
\text { mortality, \% }\end{array}$ & Comparison & Comment \\
\hline Weixler et al, $2020^{1}$ & $2000-2017$ & $\begin{array}{l}\text { Total: } 801 \\
\text { LT: } 638 \\
\text { ECC: } 183\end{array}$ & $\begin{array}{l}\text { Overall: } 1.0 \\
\text { LT: } 0.5 \\
\text { ECC: } 3.1\end{array}$ & $\begin{array}{l}\text { Propensity-score matched: age, } \\
\text { fenestration, heterotaxy, } \\
\text { ventricular dominance and } \\
\text { concomitant procedures }\end{array}$ & $P<.01$ in mortality in favor of LT. \\
\hline Mery et al, $2019^{2}$ & $1995-2016$ & $\begin{array}{l}\text { Total: } 610 \\
\text { LT: } 147 \\
\text { ECC: } 463\end{array}$ & Overall: 0.5 & $\begin{array}{l}\text { Demographics unavailable for } \\
\text { Fontan-type comparison. } \\
\text { Fontan type not considered a } \\
\text { risk factor. }\end{array}$ & $\begin{array}{l}\text { No difference reported in } \\
\text { mortality or morbidity. }\end{array}$ \\
\hline Downing et al, $2017^{3}$ & 1992-2009 & $\begin{array}{l}\text { Total: } 773 \\
\text { LT: } 409 \\
\text { ECC: } 364\end{array}$ & $\begin{array}{l}\text { Overall: } 3.5 \\
\text { LT: NR } \\
\text { ECC: NR }\end{array}$ & $\begin{array}{l}\text { Demographics unavailable for } \\
\text { Fontan-type comparison. } \\
\text { Fontan type included in } \\
\text { multivariable risk factor } \\
\text { analysis. }\end{array}$ & $\begin{array}{l}\text { No difference reported in } \\
\text { mortality. }\end{array}$ \\
\hline Ono et al, $2016^{4}$ & $1994-2015$ & $\begin{array}{l}\text { Total: } 434 \\
\text { LT: } 50 \\
\text { ECC: } 384\end{array}$ & $\begin{array}{l}\text { Overall: } 2 \\
\text { LT: } 6 \\
\text { ECC: } 2\end{array}$ & $\begin{array}{l}\text { ECC cohort had more right } \\
\text { ventricular dominance, HLHS, } \\
\text { and heterotaxy, and fewer } \\
\text { concomitant procedures and } \\
\text { fenestrations at time of Fontan. }\end{array}$ & $\begin{array}{l}P=.02 \text { in mortality in favor of } \\
\text { ECC. }\end{array}$ \\
\hline Nakano et al, $2015^{5}$ & 1994-2014 & $\begin{array}{l}\text { Total: } 500 \\
\text { LT: } 0 \\
\text { ECC: } 500\end{array}$ & $\begin{array}{l}\text { Overall: } 0.4 \\
\text { LT: N/A } \\
\text { ECC: } 0.4\end{array}$ & Only ECC & Only looked at ECC. \\
\hline Iyengar et al, $2014^{6}$ & $1975-2010$ & $\begin{array}{l}\text { Total: } 1071 \\
\text { LT: } 296 \\
\text { ECC: } 536\end{array}$ & $\begin{array}{l}\text { Overall: } 3.5 \\
\quad \text { (including } \\
\quad \text { AP Fontan) } \\
\text { LT: } 2.0(6 / 269) \\
\text { ECC: } 1.3(7 / 536)\end{array}$ & $\begin{array}{l}\text { Multivariable models accounting } \\
\text { for common risk factors } \\
\text { performed (including } \\
\text { ventricular dominance and } \\
\text { heterotaxy) to compare LT and } \\
\text { ECC patients. }\end{array}$ & $\begin{array}{l}\text { No difference reported in } \\
\text { mortality. }\end{array}$ \\
\hline Rogers et al, $2012^{7}$ & $1992-2009$ & $\begin{array}{l}\text { Total: } 771 \\
\text { LT: } 409 \\
\text { ECC: } 362\end{array}$ & $\begin{array}{l}\text { Overall: } 3.5 \\
\text { LT: NR } \\
\text { ECC: NR }\end{array}$ & $\begin{array}{l}\text { Demographics unavailable for } \\
\text { Fontan-type comparison. } \\
\text { Multivariable analysis } \\
\text { performed including all } \\
\text { preoperative risk factors. }\end{array}$ & $\begin{array}{l}P=.196 ; \text { no difference in } \\
\text { mortality. ECC associated with } \\
\text { prolonged pleural drainage and } \\
\text { hospital stay (due to longer } \\
\text { support times). }\end{array}$ \\
\hline Stewart et al, $2012^{8}$ & $2000-2009$ & $\begin{array}{l}\text { Total: } 2747 \\
\text { LT: } 1017 \\
\text { ECC: } 1730\end{array}$ & $\begin{array}{l}\text { Overall: } 1.6 \\
\text { LT: } 0.9 \\
\text { ECC: } 2.1\end{array}$ & $\begin{array}{l}\text { Unadjusted and multivariable } \\
\text { analyses (age, weight, and all } \\
\text { preoperative risk factors) } \\
\text { performed, including logistic } \\
\text { and linear regressions }\end{array}$ & $\begin{array}{l}P=.02 \text { in mortality in favor of } \\
\text { LT. }\end{array}$ \\
\hline $\begin{array}{l}\text { Robbers-Visser } \\
\text { et al, } 2010^{9}\end{array}$ & $1988-2008$ & $\begin{array}{l}\text { Total: } 209 \\
\text { LT: } 102 \\
\text { ECC: } 107\end{array}$ & $\begin{array}{l}\text { Overall: } 4 \\
\text { LT: } 3.9 \\
\text { ECC: } 4.7\end{array}$ & $\begin{array}{l}\text { Preoperative risk factors } \\
\text { accounted for in multivariable } \\
\text { analysis. HLHS and tricuspid } \\
\text { atresia more common in ECC } \\
\text { group. }\end{array}$ & $\begin{array}{l}\text { No difference reported in } \\
\text { mortality or morbidity. }\end{array}$ \\
\hline Brown et al, $2010^{10}$ & $1992-2008$ & $\begin{array}{l}\text { Total: } 280 \\
\text { LT: } 220 \\
\text { ECC: } 0\end{array}$ & $\begin{array}{l}\text { Overall: } 0.5 \\
\text { LT: } 0.5 \\
\text { ECC: N/A }\end{array}$ & Only LT & Only looked at LT. \\
\hline Salazar et al, $2010^{11}$ & $2002-2008$ & $\begin{array}{l}\text { Total: } 226 \\
\text { LT: } 69 \\
\text { ECC: } 157\end{array}$ & $\begin{array}{l}\text { Overall: } 1.3 \\
\text { LT: } 1.4 \\
\text { ECC: } 1.3\end{array}$ & $\begin{array}{l}\text { Full demographics unavailable } \\
\text { for Fontan-type comparison. } \\
\text { Risk factors included in } \\
\text { multivariable analysis. No } \\
\text { difference in concomitant } \\
\text { procedures at the time of } \\
\text { Fontan. }\end{array}$ & $\begin{array}{l}\text { No difference in mortality. } \\
\text { LT associated with longer ICU } \\
\text { stay }(P=.022) \text { and total } \\
\text { hospital stay }(P=.017)\end{array}$ \\
\hline
\end{tabular}


TABLE 1. Continued

\begin{tabular}{|c|c|c|c|c|c|}
\hline Authors & Dates & Number & $\begin{array}{c}\text { Early } \\
\text { mortality, \% }\end{array}$ & Comparison & Comment \\
\hline Tweddell et al, $2009^{12}$ & 1994-2007 & $\begin{array}{l}\text { Total: } 256 \\
\text { LT: } 81 \\
\text { ECC: } 175\end{array}$ & $\begin{array}{l}\text { Overall: } 2 \\
\text { LT: NR } \\
\text { ECC: NR }\end{array}$ & $\begin{array}{l}\text { Multivariable analysis performed } \\
\text { including preoperative risk } \\
\text { factors (excluding heterotaxy). }\end{array}$ & $\begin{array}{l}\text { No difference reported in } \\
\text { mortality or morbidity. }\end{array}$ \\
\hline Kim et al, $2008^{13}$ & 1996-2006 & $\begin{array}{l}\text { Total: } 200 \\
\text { LT: } 0 \\
\text { ECC: } 200\end{array}$ & $\begin{array}{l}\text { Overall: } 3 \\
\text { LT: N/A } \\
\text { ECC: } 3\end{array}$ & Only LT & Only looked at ECC. \\
\hline Hirsch et al, $2008^{14}$ & $1992-2007$ & $\begin{array}{l}\text { Total: } 636 \\
\text { LT: } 585 \\
\text { ECC: } 51\end{array}$ & $\begin{array}{l}\text { Overall: } 4 \\
\text { LT: NR } \\
\text { ECC: NR }\end{array}$ & $\begin{array}{l}\text { ECC was performed in patients } \\
\text { with anatomy not amenable to } \\
\text { LT technique. Group } \\
\text { comparison is not accurate due } \\
\text { to selection bias. }\end{array}$ & $\begin{array}{l}P=.02 \text { in mortality in favor of } \\
\text { LT. ECC associated with } \\
\text { prolonged effusions }(P=.01) \\
\text { and atrial arrhythmias } \\
(P=.02) \text {. } \\
\text { Complicated by minimal } \\
\text { fenestration use in ECC }(35 \%) \\
\text { vs } 100 \% \text { in LT. }\end{array}$ \\
\hline
\end{tabular}

$L T$, Lateral tunnel; $E C C$, extracardiac conduit; $N R$, not reported; $H L H S$, hypoplastic left heart syndrome; $N / A$, not applicable; $A P$, atriopulmonary; $I C U$, intensive care unit.

that dilation of the pathway (through enlarged conduits or dilated intra-atrial tunnels) results in substantial energy loss. ${ }^{19}$ Contrary to the above evidence, Bove and colleagues ${ }^{26}$ in their assessment of the fluid dynamics in various Fontan configurations, reported that the lowest energy loss was noted in LT Fontan, particularly following hemi-Fontan construction. They theorized that this may be due to the ease of caval offset and flaring of the cavopulmonary anastomosis, avoiding caval flow clashing and turbulence.

Although interesting, these fluid dynamic studies have not been able to profoundly influence our Fontan surgery and at this stage, do not seem to help us identify the superiority of one of these techniques.

\section{SIZE OF FONTAN PATHWAY}

One potential disadvantage of the ECC is its lack of capacity for growth. Any long-term outcomes may be affected by the size of conduit used. Early studies noted that IVC diameter at 2 to 4 years is approximately $80 \%$ of adult size, with significant variability among patients. ${ }^{27}$ Several studies that examined ideal conduit size in relation to long-term outcomes and exercise capacity concluded that conduit oversizing may be more detrimental to outcomes owing to flow stagnation, energy loss, and the increased risk of thromboembolic events. ${ }^{28,29}$ In an exercise study analysis, Lee and colleagues ${ }^{30}$ recently identified that the ideal conduit size is $12.5 \mathrm{~mm} / \mathrm{m}^{2}$ (16 to $18 \mathrm{~mm}$ on average) and that larger conduit sizes are worse. Others have claimed that Fontan-associated liver disease may be higher with ECC, especially with smaller conduits. ${ }^{30}$

\section{EARLY OUTCOMES}

There is a considerable variation in mortality following the 2 techniques. Most would consider the early outcomes of these techniques equivalent, but 2 articles reported significant differences. Weixler and colleagues ${ }^{1}$ described their experience with $>800$ patients from the Boston group between 2000 and 2017, with the majority undergoing a LT Fontan $(n=638)$. They reported a higher rate of early mortality following ECC Fontan compared with their LT cohort ( $3.1 \%$ vs $0.5 \% ; P<.01)$, despite the fact that patients who underwent LT seemed to have more adverse risk factors. Patients who underwent LT had a higher incidence of right ventricular dominance and hypoplastic left heart syndrome (HLHS), and higher pulmonary artery pressure and pulmonary vascular resistance. A 2012 analysis of 2747 Fontan procedures performed in 68 centers between 2000 and 2009 recorded in the Society of Thoracic Surgeons (STS) database showed higher mortality in patients who underwent ECC Fontan $(2.1 \%$ vs $0.9 \% ; P=.02) .{ }^{8}$ This is in contrast to a recent large single-center study from Philadelphia of 773 patients from 1992 to 2009 that reported a higher overall operative mortality of $3.5 \%$, with no difference between ECC and LT. ${ }^{3}$ In addition, the Australia and New Zealand Fontan Registry reported a low early mortality rate of $1.3 \%$ for ECC across a similar era (1997-2010) and up to $2.0 \%$ operative mortality for the LT technique $(P=.8)^{6,31}$

Early morbidity following Fontan operations can present as prolonged pleural effusions, hospital stay, and early Fontan takedown. The Boston group recently noted that despite longer cross-clamp times $(P=.01)$ and bypass times $(P<.001)$ in the LT cohort, there was no difference in early postoperative morbidity between the 2 techniques, other than 
TABLE 2. Late outcomes of contemporary techniques

\begin{tabular}{|c|c|c|c|c|c|c|}
\hline Authors & Dates & $\mathbf{n}$ & $\begin{array}{l}\text { Follow-up, } \\
\text { y (median) }\end{array}$ & Survival, \% & Comparison & Comment \\
\hline Weixler et al, $2020^{1}$ & $2000-2017$ & $\begin{array}{l}\text { Total: } 801 \\
\text { LT: } 638 \\
\text { ECC: } 183\end{array}$ & 4.8 & $\begin{array}{l}5 \text { y: LT, } 96.4 \text { vs ECC, } 92.0 \\
10 \text { y: LT, } 94.5 \text { vs ECC, } \\
91.4 \\
20 \text { y: LT, } 93.9 \text { vs ECC, } \\
\quad 90.8\end{array}$ & $\begin{array}{l}\text { Propensity-score } \\
\text { matched: age, } \\
\text { fenestration, } \\
\text { heterotaxy, ventricular } \\
\text { dominance, and } \\
\text { concomitant } \\
\text { procedures }\end{array}$ & $\begin{array}{l}\text { Improved survival in } \mathrm{LT} \\
\text { group }(\mathrm{HR}, 2.7 ; \\
P<.05) \text {. Better } \\
\text { freedom from failure in } \\
\text { LT group }(P=.02) \text {. } \\
\text { Pleural effusions more } \\
\text { common in ECC group } \\
(P=.01) .\end{array}$ \\
\hline Deshaies et al, $2019^{15}$ & 1974-2012 & $\begin{array}{l}\text { Total: } 522 \\
\text { LT: } 218 \\
\text { ECC: } 192\end{array}$ & 11.6 & $\begin{array}{l}5 \mathrm{y}: 98.3 \\
10 \mathrm{y}: 94.7 \\
20 \mathrm{y}: 78.9\end{array}$ & $\begin{array}{l}\text { Demographics } \\
\text { comparison between } \\
\text { LT and ECC } \\
\text { unavailable. } \\
\text { Multivariable analysis } \\
\text { of thromboembolic risk } \\
\text { performed between LT } \\
\text { and ECC (including } \\
\text { arrhythmias and } \\
\text { thromboprophylaxis). }\end{array}$ & $\begin{array}{l}\text { Includes AP Fontan. No } \\
\text { difference reported in } \\
\text { survival or arrhythmias. } \\
\text { Lower rate of } \\
\text { thromboembolic events } \\
\text { in ECC group } \\
\text { compared with LT (HR, } \\
0.34 ; 95 \% \text { CI, 0.13- } \\
0.91) \text {. }\end{array}$ \\
\hline Mery et al, $2019^{2}$ & $1995-2016$ & $\begin{array}{l}\text { Total: } 610 \\
\text { LT: } 147 \\
\text { ECC: } 463\end{array}$ & 6.8 & $\begin{array}{l}5 \text { y: } 97 \\
10 y: 94 \\
15 \text { y: } 92\end{array}$ & $\begin{array}{l}\text { Demographics } \\
\text { unavailable for Fontan- } \\
\text { type comparison. } \\
\text { Fontan type not } \\
\text { considered a risk factor. }\end{array}$ & $\begin{array}{l}\text { No difference reported in } \\
\text { survival or failure. } \\
\text { Higher incidence of } \\
\text { arrhythmia in the LT } \\
\text { group compared with } \\
\text { the ECC group } \\
(P=.002) \text {. }\end{array}$ \\
\hline Downing et al, $2017^{3}$ & 1992-2009 & $\begin{array}{l}\text { Total: } 773 \\
\text { LT: } 409 \\
\text { ECC: } 364\end{array}$ & 9 & $\begin{array}{l}10 \text { y: } 90(95 \% \text { CI, } 88-92) \\
20 \text { y: } 74(95 \% \text { CI, 67-80) }\end{array}$ & $\begin{array}{l}\text { Demographics } \\
\text { unavailable for Fontan- } \\
\text { type comparison. } \\
\text { Fontan type included in } \\
\text { multivariable risk } \\
\text { factor analysis. }\end{array}$ & $\begin{array}{l}\text { Survival with intact } \\
\text { Fontan circulation. } \\
\text { Fontan type did not } \\
\text { impact late outcomes } \\
\text { (survival or failure). }\end{array}$ \\
\hline Iyengar et al, $2014^{6}$ & $1975-2010$ & $\begin{array}{l}\text { Total: } 1006 \\
\text { LT: } 271 \\
\text { ECC: } 532\end{array}$ & NR & $\begin{array}{l}15 \text { y: } 93(95 \% \text { CI, } 90-95) \\
20 \text { y: } 90(95 \% \text { CI, 86-93) } \\
25 \text { y: } 83 \text { (95\% CI, 75-89) }\end{array}$ & $\begin{array}{l}\text { Multivariable models } \\
\text { accounting for common } \\
\text { risk factors (including } \\
\text { ventricular dominance } \\
\text { and heterotaxy) } \\
\text { performed to compare } \\
\text { LT and ECC patients. }\end{array}$ & $\begin{array}{l}\text { No difference reported in } \\
\text { survival between LT } \\
\text { and ECC } \\
\text { Higher rate of SVT in LT } \\
\text { (HR, } 3.1 ; P=.019) \text {. No } \\
\text { reported difference in } \\
\text { failure or other adverse } \\
\text { events. }\end{array}$ \\
\hline Nakano et al, $2015^{5}$ & 1994-2014 & $\begin{array}{l}\text { Total: } 500 \\
\text { LT: } 0 \\
\text { ECC: } 500\end{array}$ & 7 & $15 \mathrm{y}: 93$ & Only ECC & Only ECC in the study. \\
\hline Ono et al, $2016^{4}$ & $1994-2015$ & $\begin{array}{l}\text { Total: } 434 \\
\text { LT: } 50 \\
\text { ECC: } 384\end{array}$ & 6.6 & $15 \mathrm{y}: 92.3$ & $\begin{array}{l}\text { ECC cohort had more } \\
\text { right ventricular } \\
\text { dominance, HLHS, } \\
\text { heterotaxy, and fewer } \\
\text { concomitant } \\
\text { procedures and } \\
\text { fenestrations at time of } \\
\text { Fontan. }\end{array}$ & $\begin{array}{c}\text { No reported difference in } \\
\text { survival. Predicted } \% \\
\text { of peak } \mathrm{VO}_{2} \text { higher in } \\
\text { ECC group }(P<.001)\end{array}$ \\
\hline
\end{tabular}


TABLE 2. Continued

\begin{tabular}{|c|c|c|c|c|c|c|}
\hline Authors & Dates & $\mathbf{n}$ & $\begin{array}{l}\text { Follow-up, } \\
\text { y (median) }\end{array}$ & Survival, \% & Comparison & Comment \\
\hline Balaji et al, $2014^{16}$ & $1998-2008$ & $\begin{array}{l}\text { Total: } 1271 \\
\text { LT: } 602 \\
\text { ECC: } 669\end{array}$ & 9.2 & NR & $\begin{array}{l}\text { Univariable and } \\
\text { multivariable analysis } \\
\text { performed for ECC and } \\
\text { LT comparison. ECC } \\
\text { had more left } \\
\text { ventricular dominance } \\
\text { and older age at Fontan } \\
\text { on univariable analysis. }\end{array}$ & $\begin{array}{l}\text { Higher rate of early } \\
\text { postoperative } \\
\text { bradyarrhythmia in } \\
\text { ECC group }(P<.001) \\
\text { No difference at late } \\
\text { follow-up between LT } \\
\text { and ECC. }\end{array}$ \\
\hline $\begin{array}{c}\text { Robbers-Visser } \\
\text { et al, } 2010^{9}\end{array}$ & $1988-2008$ & $\begin{array}{l}\text { Total: } 209 \\
\text { LT: } 102 \\
\text { ECC: } 107\end{array}$ & 4.3 & $\begin{array}{l}\text { Freedom from failure } \\
\text { (mortality and failure) } \\
3 \text { y: LT, } 85 \text { vs ECC, } 88 \\
6 \text { y: LT, } 83 \text { vs ECC, } 79\end{array}$ & $\begin{array}{l}\text { Preoperative risk factors } \\
\text { accounted for in } \\
\text { multivariable analysis. } \\
\text { HLHS and tricuspid } \\
\text { atresia more common in } \\
\text { ECC group. }\end{array}$ & $\begin{array}{l}\text { No difference reported in } \\
\text { survival/freedom from } \\
\text { failure }(P=.93) \text {. } \\
\text { Higher rate of } \\
\text { arrhythmia in the LT } \\
\text { group on log-rank } \\
\text { analysis }(P=.022) .\end{array}$ \\
\hline Hirsch et al, $2008^{14}$ & $1992-2007$ & $\begin{array}{l}\text { Total: } 636 \\
\text { LT: } 585 \\
\text { ECC: } 51\end{array}$ & 4 & $\begin{array}{l}5 \mathrm{y}: 95 \\
10 \mathrm{y}: 93 \\
14 \mathrm{y}: 91\end{array}$ & $\begin{array}{l}\text { ECC was performed in } \\
\text { patients with anatomy } \\
\text { not amenable to LT } \\
\text { technique. Group } \\
\text { comparison is } \\
\text { inaccurate due to } \\
\text { selection bias. }\end{array}$ & $\begin{array}{l}\text { Unable to compare } \\
\text { difference due to } \\
\text { patient selection bias. }\end{array}$ \\
\hline Mitchell et al, $2006^{17}$ & 1992-1999 & $\begin{array}{l}\text { Total: } 322 \\
\text { LT: } 262 \\
\text { ECC: } 48\end{array}$ & 8.3 & $\begin{array}{l}\text { Freedom from death and } \\
\text { transplantation } \\
5 \text { y: } 94.9(95 \% \text { CI, 91.6- } \\
\text { 97.0) } \\
8 \text { y: } 93.9(95 \% \mathrm{CI}, 90.1- \\
96.2)\end{array}$ & $\begin{array}{l}\text { Comparison of } \\
\text { demographics between } \\
\text { LT and ECC } \\
\text { unavailable. } \\
\text { Univariable and } \\
\text { multivariable analyses } \\
\text { performed. No } \\
\text { difference in } \\
\text { preoperative or } \\
\text { operative variables } \\
\text { between group } \\
\text { outcomes. }\end{array}$ & $\begin{array}{l}\text { No difference reported in } \\
\text { survival/freedom from } \\
\text { failure or } \\
\text { hospitalization } \\
(P=.062) .\end{array}$ \\
\hline
\end{tabular}

$\overline{L T}$, Lateral tunnel; $E C C$, extracardiac conduit; $H R$, hazard ratio; $A P$, atriopulmonary; $C I$, confidence interval; $S V T$, supraventricular tachycardia; $H L H S$, hypoplastic left heart syndrome; $\mathrm{VO}_{2}$, oxygen consumption; $N R$, not reported.

prolonged pleural effusions (3.9\% for LT vs $8.6 \%$ for ECC; $P<.01){ }^{1}$ Similarly, the Australia and New Zealand cohort reported no difference between LT and ECC in early failure $(6 \%$ vs $4 \% ; P=.2)$, prolonged effusions $(6 \%$ vs $8 \% ; P=.2$ ), or a composite of early adverse outcomes, including length of stay $(17 \%$ vs $13 \% ; P=.7) .{ }^{6}$ However, the STS database review, which accounted for patient characteristics, procedural factors, and center volume, found worse early outcomes on multivariable analysis in the ECC group with more takedown/revisions $(0.7 \%$ for LT vs $1.7 \%$ for ECC; $P=.03$ ), increased length of stay (9 days vs 10 days; $P<.001)$, and postoperative complications $(32 \%$ vs $45 \%)^{8}$

\section{LONG-TERM SURVIVAL, FREEDOM FROM HEART TRANSPLANTATION, AND FONTAN FAILURE}

There have been several large publications of various Fontan cohort outcomes detailing the differences in outcomes between LT and ECC (Table 2). The Australia and New Zealand Fontan Registry reviewed the long-term outcomes of 271 LT and 532 ECC Fontan patients, which demonstrated relatively similar survival and freedom from failure in the 2 groups. $^{32}$ Similarly, Downing and colleagues $^{3}$ from Philadelphia noted that the type of Fontan did not predict early or late survival, freedom from transplantation, or Fontan failure. 
The recent publication of Fontan outcomes from the Boston Children's Hospital has reopened this conversation. The long-term survival was better in the LT group compared with the ECC group (hazard ratio [HR], 2.7; $P<.05$ ), in contrast to most of the published data worldwide, which consistently demonstrates no difference between techniques. ${ }^{1,3,32,33}$ This difference in outcomes in the Boston group is also noted in their freedom from Fontan failure $(P=.02)$ and their propensity score analysis; however, their propensity score analysis, which included heterotaxy syndromes and concomitant procedures, failed to show a significant difference in mortality at a 10-year follow-up.

\section{Arrhythmias}

Sinus node dysfunction and chronotropic incompetence have been shown to be common early and late after Fontan surgery and to impair exercise tolerance. ${ }^{6,32,34}$ Recently, chronotropic incompetence and decline in peak exercise capacity have been shown to predict mortality and the need for hospitalization and transplantation. ${ }^{35}$ Avoidance of an atrial incision and suture lines is thought to reduce the rate of atrial arrhythmias, with their prevalence increasing with time. The exclusion of the atrium in the ECC Fontan also theoretically spares the atrial wall from distension and subsequent risk of arrhythmia. This theory is supported by Robbers-Visser and colleagues, ${ }^{9}$ who reported higher arrhythmic burden in their LT cohort compared with their ECC cohort $(\mathrm{n}=277$; freedom from arrhythmia, $83 \%$ vs $92 \%$ at 6 years; $P=.02$ ). ${ }^{9}$ In addition, a recent study from Texas of 610 patients reported higher rates of arrhythmia in the LT group $(P=.002) .{ }^{2}$ However, a large review by Balaji and colleagues of 1271 patients across 14 centers in 2014 reported no difference in the rate of late tachyarrhythmias between LT and ECC patients. ${ }^{16}$ Weixler and colleagues' recent comparison also noted no differences in pacemaker implantation, tachyarrhythmia ( $4.2 \%$ for LT vs $2.5 \%$ for ECC; $P=.3$ ) or sinus node dysfunction (4.9 for LT vs 1.8 for ECC; $P=.09$ ) between their 2 groups. ${ }^{1}$

Clearly, the incidence of reported arrhythmias will differ with varying lengths of follow-up. ${ }^{36,37}$ Currently, there is no consensus on which technique results in higher arrhythmic burden. ${ }^{38}$ As the contemporary Fontan patients age and their arrhythmic burden increases, the different management options will become more important. As Marshall and colleagues ${ }^{39}$ reported in their recent review of Fontan arrhythmia management, lateral tunnel patients maintain transvenous atrial access if atrial pacing is required.

\section{THROMBOEMBOLIC EVENTS}

Thromboembolic events contribute to significant morbidity following the Fontan operation. ${ }^{40}$ Until recently, there has been no consistently reported difference in thrombotic events between LT and ECC ${ }^{1,9,41}$; however, in a recent report by Deshaies and colleagues, ${ }^{15}$ a multivariable timeadjusted analysis of 522 patients across 12 institutions showed that ECC is associated with a lower incidence of thromboembolic events with a similar arrhythmic burden. ${ }^{15}$ The Boston group reported a large discrepancy in postoperative warfarin use between ECC and LT patients $33 \%$ vs $4.7 \%$ ), which the authors attributed to pre-Fontan thromboembolic events. ${ }^{1}$ Although no difference in overall post-Fontan thromboembolic events between the groups, the majority of early ECC deaths were attributed to thromboembolic complications. It is difficult to elucidate whether this is due the prosthetic material used in ECC or a preexisting tendency of these patients toward thrombosis. Neither pre-Fontan thrombosis nor warfarin use was included in the propensity score analyses, and differences that might have impacted their overall outcomes likely remained.

\section{OTHER CONSIDERATIONS}

The heterogeneity of patients undergoing the Fontan operations makes comparison of studies difficult. Heterotaxy syndromes and venous anomalies are common in the single-ventricle population, and there seems to be a tendency to favor ECC in this setting. ${ }^{8}$ In patients with interrupted IVC, the Kawashima procedure can be useful; however, there is inevitable formation of pulmonary arteriovenous malformations. A technique with a Y-graft ECC has been theorized to equally distribute hepatic flow (and thereby hepatic factor) to both lungs. ${ }^{42}$ Another variation that can be useful in complex rerouting of the systemic venous flow is the intra/extracardiac Fontan, originally described by Vargas and colleagues. ${ }^{43}$

\section{DISCUSSION}

The surgical technique of the Fontan procedure has evolved since its conception but we are still uncertain whether the lateral tunnel and the extracardiac conduit, the most widely used techniques, are equivalent. Both were studied with a plethora of fluid dynamics studies to determine the ideal Fontan pathway. The early work by de Leval and others helped identify large pitfalls in constructing the Fontan pathways incorporating the entire atrium and highlighted the importance of creating the most streamlined pathway. ${ }^{19,24}$ However, as Tang and colleagues ${ }^{25}$ demonstrated, there is significant variability within each of these techniques. These studies have not yet helped us to identify the relative superiority of LT and ECC.

There was hope that patients operated with the extracardiac conduit would have less arrhythmia, and globally, there seems to have been a large shift toward performing ECC over LT. ${ }^{7,15,32}$ However, after almost 3 decades, there is little evidence of the superiority of one technique over the other in terms of long-term outcomes.

Importantly, there is recent evidence of worse early outcomes after ECC compared to the LT technique. ${ }^{1}$ Published 
rates of operative mortality vary substantially, particularly for the ECC technique. ${ }^{1,3,6}$ This variability might be the reflection of the technical challenges of performing this operation accurately. The earlier fluid dynamics studies have clearly demonstrated that small changes in anastomotic angles and offset have profound effects on flow. In addition, the anastomosis of an extracardiac conduit to the pulmonary arteries carries the potential for significant distortion of the PAs, particularly at a young age. Technical issues such as these may present as early or late adverse outcomes and have recently been demonstrated to contribute substantially to patient mortality. ${ }^{44}$

Despite the simple design of the extracardiac conduit, its realization and accurate reproducibility is more complicated. It should be noted that groups who demonstrated better results with the extracardiac conduit, such as the Australia and New Zealand group, appear to proceed with the Fontan operation at a later age (mean, 4.7 years) compared with many of the larger North American institutions. ${ }^{1,3,6}$ Performing the ECC technique in larger patients may reduce IVCconduit mismatch and minimize PA distortion.

There is significant heterogeneity in the patients requiring the Fontan operation and it is possible that one of these techniques may be better suited for specific patients. For example, the pulmonary arterial and systemic venous anomalies and apicocaval juxtaposition frequently encountered in heterotaxy syndromes may be better served by one of the techniques, depending on the anatomy. In addition, patients with HLHS, who have been noted to develop arteriovenous malformations more frequently and thus may require earlier Fontan completion, may be better served by LT Fontan. It should be noted that in most series describing late outcomes, the reason to choose one or the other technique were not specified, other than institution or surgeon preference.

\section{CONCLUSIONS}

Whether LT or ECC is the superior technique remains controversial. Reports of worse early adverse outcomes after ECC may reflect the technical complexities of accurately performing this technique. As institutions and surgeons tend to favor one technique over the other, comparison of outcomes has become difficult. Because of this equipoise, one may wonder whether further prospective research will be able to identify which technique should be used in specific circumstances.

\section{Conflict of Interest Statement}

\section{Dr d'Udekem is a consultant for Actelion.}

The Journal policy requires editors and reviewers to disclose conflicts of interest and to decline handling or reviewing manuscripts for which they may have a conflict of interest. The editors and reviewers of this article have no conflicts of interest.
We acknowledge support provided to the Murdoch Children's Research Institute through the Victorian Government's Operational Infrastructure Support Programme.

\section{References}

1. Weixler VHM, Zurakowski D, Kheir J, Guariento A, Kaza AK, Baird CW, et al. Fontan with lateral tunnel is associated with improved survival compared with extracardiac conduit. J Thorac Cardiovasc Surg. 2020;159:1480-91.e2.

2. Mery CM, De León LE, Trujillo-Diaz D, Ocampo EC, Dickerson HA, Zhu H, et al. Contemporary outcomes of the Fontan operation: a large singleinstitution cohort. Ann Thorac Surg. 2019;108:1439-46.

3. Downing TE, Allen KY, Glatz AC, Rogers LS, Ravishankar C, Rychik J, et al. Long-term survival after the Fontan operation: twenty years of experience at a single center. J Thorac Cardiovasc Surg. 2017;154 243-53.e2.

4. Ono M, Kasnar-Samprec J, Hager A, Cleuziou J, Burri M, Langenbach C, et al. Clinical outcome following total cavopulmonary connection: a 20-year singlecentre experience. Eur J Cardiothorac Surg. 2016;50:632-41.

5. Nakano T, Kado H, Tatewaki H, Hinokiyama K, Oda S, Ushinohama H, et al. Results of extracardiac conduit total cavopulmonary connection in 500 patients. Eur J Cardiothorac Surg. 2015;48:825-32.

6. Iyengar AJ, Winlaw DS, Galati JC, Celermajer DS, Wheaton GR, Gentles TL, et al. Trends in Fontan surgery and risk factors for early adverse outcomes after Fontan surgery: the Australia and New Zealand Fontan registry experience. $J$ Thorac Cardiovasc Surg. 2014;148:566-75.

7. Rogers LS, Glatz AC, Ravishankar C, Spray TL, Nicolson SC, Rychik J, et al. 18 years of the Fontan operation at a single institution: results from 771 consecutive patients. J Am Coll Cardiol. 2012;60:1018-25.

8. Stewart RD, Pasquali SK, Jacobs JP, Benjamin DK, Jaggers J, Cheng J, et al. Contemporary Fontan operation: association between early outcome and type of cavopulmonary connection. Ann Thorac Surg. 2012;93:1254-60; discussion 1261.

9. Robbers-Visser D, Miedema M, Nijveld A, Boersma E, Bogers AJ, Haas F, et al. Results of staged total cavopulmonary connection for functionally univentricular hearts; comparison of intra-atrial lateral tunnel and extracardiac conduit. Eur J Cardiothorac Surg. 2010;37:934-41.

10. Brown JW, Ruzmetov M, Deschner BW, Rodefeld MD, Turrentine MW. Lateral tunnel Fontan in the current era: is it still a good option? Ann Thorac Surg. 2010; 89:556-62; discussion 562-3.

11. Salazar JD, Zafar F, Siddiqui K, Coleman RD, Morales DLS, Heinle JS, et al. Fenestration during Fontan palliation: now the exception instead of the rule. $J$ Thorac Cardiovasc Surg. 2010;140:129-36.

12. Tweddell JS, Nersesian M, Mussatto KA, Nugent M, Simpson P, Mitchell ME et al. Fontan palliation in the modern era: factors impacting mortality and morbidity. Ann Thorac Surg. 2009;88:1291-9.

13. Kim SJ, Kim WH, Lim HG, Lee JY. Outcome of 200 patients after an extracardiac Fontan procedure. J Thorac Cardiovasc Surg. 2008;136:108-16.

14. Hirsch JC, Goldberg C, Bove EL, Salehian S, Lee T, Ohye RG, et al. Fontan operation in the current era: a 15-year single institution experience. Ann Surg. 2008; 248:402-10.

15. Deshaies C, Hamilton RM, Shohoudi A, Trottier H, Poirier N, Aboulhosn J, et al Thromboembolic risk after atriopulmonary, lateral tunnel, and extracardiac conduit Fontan surgery. J Am Coll Cardiol. 2019;74:1071-81.

16. Balaji S, Daga A, Bradley DJ, Etheridge SP, Law IH, Batra AJ, et al. An international multicenter study comparing arrhythmia prevalence between the intracardiac lateral tunnel and the extracardiac conduit type of Fontan operations. $J$ Thorac Cardiovasc Surg. 2014;148:576-81.

17. Mitchell ME, Ittenbach RF, Gaynor JW, Wernovsky G, Nicolson S, Spray TL. Intermediate outcomes after the Fontan procedure in the current era. J Thorac Cardiovasc Surg. 2006;131:172-80.

18. Puga FJ, Chiavarelli M, Hagler DJ. Modifications of the Fontan operation applicable to patients with left atrioventricular valve atresia or single atrioventricular valve. Circulation. 1987;76(3 Pt 2):III53-60.

19. de Leval MR, Kilner P, Gewillig M, Bull C. Total cavopulmonary connection: a logical alternative to atriopulmonary connection for complex Fontan operations. Experimental studies and early clinical experience. J Thorac Cardiovasc Surg. 1988;96:682-95.

20. Humes RA, Feldt RH, Porter CJ, Julsrud PR, Puga FJ, Danielson GK. The modified Fontan operation for asplenia and polysplenia syndromes. J Thorac Cardiovasc Surg. 1988;96:212-8. 
21. Marcelletti C, Corno A, Giannico S, Marino B. Inferior vena cava-pulmonary artery extracardiac conduit. A new form of right heart bypass. J Thorac Cardiovasc Surg. 1990;100:228-32.

22. Sharma S, Goudy S, Walker P, Panchal S, Ensley A, Kanter K, et al. In vitro flow experiments for determination of optimal geometry of total cavopulmonary connection for surgical repair of children with functional single ventricle. J Am Coll Cardiol. 1996;27:1264-9.

23. Lardo AC, Webber SA, Friehs I, del Nido PJ, Cape EG. Fluid dynamic comparison of intra-atrial and extracardiac total cavopulmonary connections. J Thorac Cardiovasc Surg. 1999; 117:697-704.

24. de Leval MR, Dubini G, Migliavacca F, Jalali H, Camporini G, Redington A, et al. Use of computational fluid dynamics in the design of surgical procedures: application to the study of competitive flows in cavo-pulmonary connections. $J$ Thorac Cardiovasc Surg. 1996;111:502-13.

25. Tang E, Restrepo M, Haggerty CM, Mirabella L, Bethel J, Whitehead KK, et al. Geometric characterization of patient-specific total cavopulmonary connections and its relationship to hemodynamics. JACC Cardiovasc Imaging. 2014;7: 215-24.

26. Bove EL, de Leval MR, Migliavacca F, Guadagni G, Dubini G. Computational fluid dynamics in the evaluation of hemodynamic performance of cavopulmonary connections after the Norwood procedure for hypoplastic left heart syndrome. J Thorac Cardiovasc Surg. 2003;126:1040-7.

27. Alexi-Meskishvili V, Ovroutski S, Ewert P, Dähnert I, Berger F, Lange PE, et al. Optimal conduit size for extracardiac Fontan operation. Eur J Cardiothorac Surg. 2000;18:690-5.

28. Itatani K, Miyaji K, Tomoyasu T, Nakahata Y, Ohara K, Takamoto S, et al. Optimal conduit size of the extracardiac Fontan operation based on energy loss and flow stagnation. Ann Thorac Surg. 2009;88:565-72; discussion 572-3.

29. Lee SY, Song MK, Kim GB, Bae EJ, Kim SH, Jang SI, et al. Relation between exercise capacity and extracardiac conduit size in patients with Fontan circulation. Pediatr Cardiol. 2019;40:1584-90.

30. Cetta F, Burkhart HM. The Fontan extracardiac conduit: one size does not fit all Transl Pediatr. 2018;7:233-4.

31. Wilson TG, Shi WY, Iyengar AJ, Winlaw DS, Cordina RL, Wheaton GR, et al. Twenty-five year outcomes of the lateral tunnel Fontan procedure. Semin Thorac Cardiovasc Surg. 2017;29:347-53.

32. d'Udekem Y, Iyengar AJ, Galati JC, Forsdick V, Weintraub RG, Wheaton GR, et al. Redefining expectations of long-term survival after the Fontan procedure: twenty-five years of follow-up from the entire population of Australia and New Zealand. Circulation. 2014;130(11 Suppl 1):S32-8.

33. Pundi KN, Johnson JN, Dearani JA, Pundi KN, Li Z, Hinck CA, et al. 40-year follow-up after the Fontan operation: long-term outcomes of 1,052 patients. $J$ Am Coll Cardiol. 2015;66:1700-10.

34. Cohen MI, Wernovsky G, Vetter VL, Wieand TS, Gaynor JW, Jacobs ML, et al. Sinus node function after a systematically staged Fontan procedure. Circulation. 1998;98(19 Suppl):II352-8; discussion II358-9.

35. Udholm S, Aldweib N, Hjortdal VE, Veldtman GR. Prognostic power of cardiopulmonary exercise testing in Fontan patients: a systematic review. Open Heart. 2018;5:e000812.

36. Quinton E, Nightingale P, Hudsmith L, Thorne S, Marshall H, Clift P, et al. Prevalence of atrial tachyarrhythmia in adults after Fontan operation. Heart. 2015; 101:1672-7.

37. Stephenson EA, Lu M, Berul CI, Etheridge SP, Idriss SF, Margossian R, et al. Arrhythmias in a contemporary Fontan cohort: prevalence and clinical associations in a multicenter cross-sectional study. J Am Coll Cardiol. 2010;56:890-6.

38. Lasa JJ, Glatz AC, Daga A, Shah M. Prevalence of arrhythmias late after the Fontan operation. Am J Cardiol. 2014;113:1184-8.

39. Marshall M, Alnoor M, Balaji S. Current treatment options of Fontan arrhythmias: management. Curr Treat Options Cardiovasc Med. 2020;22:46.

40. Alsaied T, Alsidawi S, Allen CC, Faircloth J, Palumbo JS, Veldtman GR. Strategies for thromboprophylaxis in Fontan circulation: a meta-analysis. Heart. 2015; 101:1731-7.

41. Coon PD, Rychik J, Novello RT, Ro PS, Gaynor JW, Spray TL. Thrombus formation after the Fontan operation. Ann Thorac Surg. 2001;71:1990-4.

42. Kanter KR. Alternative techniques for the Fontan operation. Oper Tech Thorac Cardiovasc Surg. 2014;19:64-79.

43. Vargas FJ, Mayer JE Jr, Jonas RA, Castaneda AR. Anomalous systemic and pulmonary venous connections in conjunction with atriopulmonary anastomosis (Fontan-Kreutzer). Technical considerations. J Thorac Cardiovasc Surg. 1987; 93:523-32.

44. Poh C, Hornung T, Celermajer DS, Radford DJ, Justo RN, Andrews D, et al. Modes of late mortality in patients with a Fontan circulation. Heart. 2020;106: 1427-31.

Key Words: Fontan, lateral tunnel, extracardiac conduit, contemporary techniques, outcomes 


\section{The Fontan operation: Recent Articles from AATS Journals}

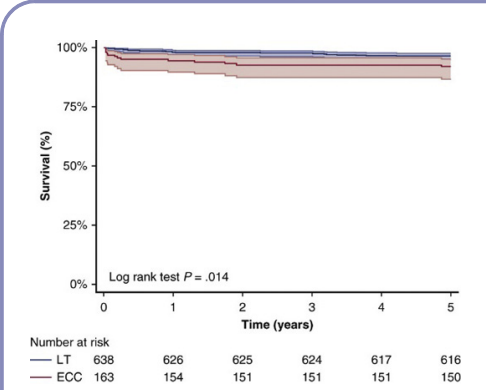

JTCVS: Fontan with lateral tunnel is associated with improved survival compared with extracardiac conduit. Weixler VHM, Zurakowski D, Kheir J, Guariento A, Kaza AK, Baird CW, Del Nido PJ, Emani SM. J Thorac Cardiovasc Surg. 2020;159(4):1480-1491.

Commentary: I don't like change. Huddleston, CB. J Thorac Cardiovasc Surg. 2020;159(4):14911492.

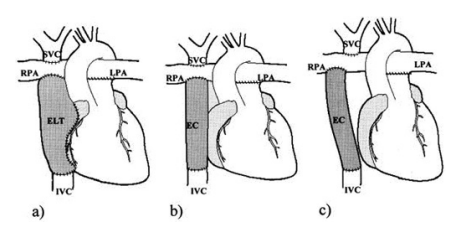

JTCVS: Fluid dynamic comparison of intra-atrial and extracardiac total cavopulmonary connections. Lardo AC, Webber SA, Friehs I, del Nido PJ, Cape EG. J Thorac Cardiovasc Surg. 1999;117(4):697-704.

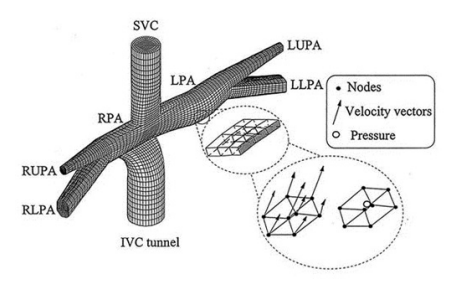

JTCVS: Use of computational fluid dynamics in the design of surgical procedures: Application to the study of competitive flows in cavo-pulmonary connections. de Leval MR, Dubini G, Migliavacca F, Jalali H, Camporini G, Redington A, Pietrabissa R. J Thorac Cardiovasc Surg. 1996;111(3):502-513.
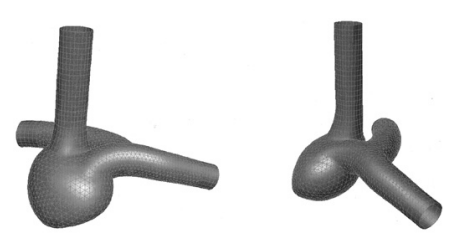

JTCVS: Computational fluid dynamics in the evaluation of hemodynamic performance of cavopulmonary connections after the Norwood procedure for hypoplastic left heart syndrome. Bove EL, de Leval MR, Migliavacca F, Guadagni G, Dubini G. J Thorac Cardiovasc Surg. 2003;126(4):1040-1047.

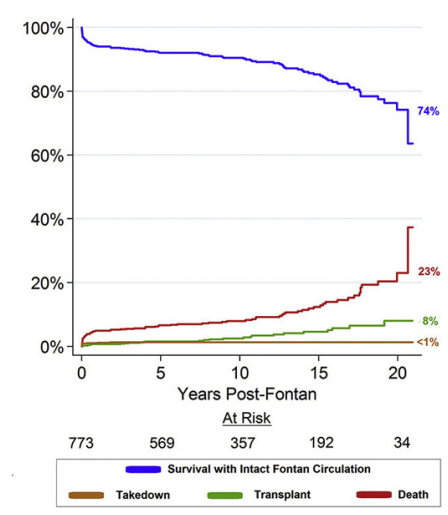

JTCVS: Long-term survival after the Fontan operation: Twenty years of experience at a single center. Downing TE, Allen KY, Glatz AC, Rogers LS, Ravishankar C, Rychik J, Faerber JA, Fuller S, Montenegro LM, Steven JM, Spray TL, Nicolson SC, Gaynor JW, Goldberg DJ. J Thorac Cardiovasc Surg. 2017;154(1):243-253.

Commentary: Is it time for some new ideas for patients undergoing the Fontan operation? Here is some food for thought. Al-Radi 00. J Thorac Cardiovasc Surg. 2017;154(1):254-255. Commentary: Fontan survival: As good as it gets? Thankavel P, Jaquiss RDB. 2017;154(1): 241-242. 

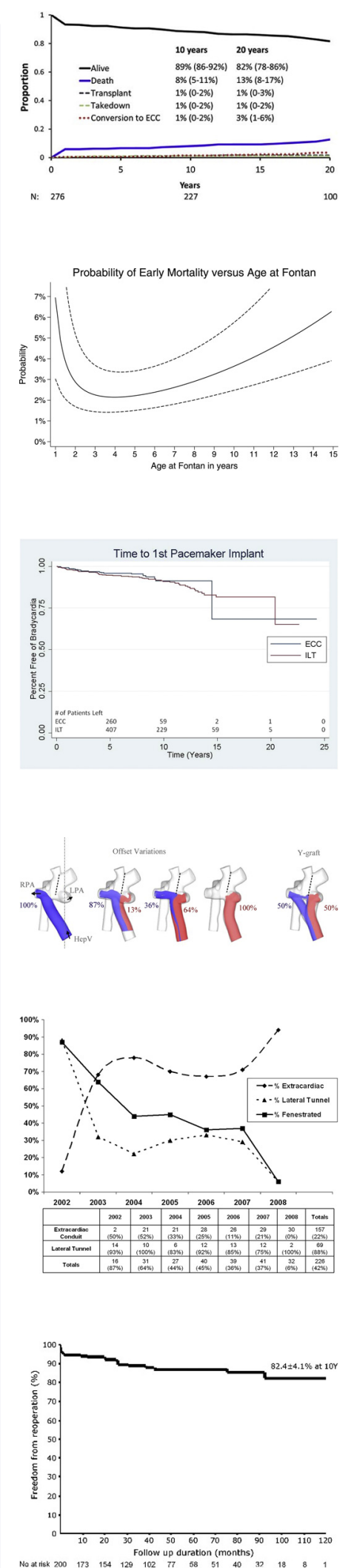

STcvS: Twenty-five year outcomes of the lateral tunnel Fontan procedure. Wilson TG, Shi WY, lyengar AJ, Winlaw DS, Cordina RL, Wheaton GR, Bullock A, Gentles TL, Weintraub RG, Justo RN, Grigg LE, Radford DJ, d'Udekem Y; Australia and New Zealand Fontan Registry. Semin Thorac Cardiovasc Surg. 2017;29(3):347-353.

Commentary: Excellence, like beauty, may be in the eyes of the beholder. Woods RK. Semin Thorac Cardiovasc Surg. 2017;29(3):354-355.

JTCVS: Trends in Fontan surgery and risk factors for early adverse outcomes after Fontan surgery: The Australia and New Zealand Fontan Registry experience. lyengar AJ, Winlaw DS, Galati JC, Celermajer DS, Wheaton GR, Gentles TL, Grigg LE, Weintraub RG, Bullock A, Justo RN, d’Udekem Y. J Thorac Cardiovasc Surg. 2014;148(2):566-575.

JTCVS: An international multicenter study comparing arrhythmia prevalence between the intracardiac lateral tunnel and the extracardiac conduit type of Fontan operations. Balaji S, Daga A, Bradley DJ, Etheridge SP, Law IH, Batra AS, Sanatani S, Singh AK, Gajewski KK, Tsao S, Singh HR, Tisma-Dupanovic S, Tateno S, Takamuro M, Nakajima H, Roos-Hesselink JW, Shah M. J Thorac Cardiovasc Surg. 2014;148(2):576-81.

OP TECHS: Alternative techniques for the Fontan operation. Kanter KR. Oper Tech Thorac Cardiovasc Surg. 2014;19(1):64-79.

JTcVS: Fenestration during Fontan palliation: Now the exception instead of the rule. Salazar JD, Zafar F, Siddiqui K, Coleman RD, Morales DL, Heinle JS, Rossano JW, Mossad EB, Fraser CD Jr. J Thorac Cardiovasc Surg. 2010;140(1):129-136.

JTCVS: Outcome of 200 patients after an extracardiac Fontan procedure. Kim SJ, Kim WH, Lim HG, Lee JY. J Thorac Cardiovasc Surg. 2008;136(1):108-16. 